\title{
Young Adult Literature in the Malaysian Secondary School
}

\author{
Mallika V. Govindarajoo ${ }^{1} \&$ Jayakaran Mukundan ${ }^{1}$ \\ ${ }^{1}$ Department of Language and Humanities Education, Faculty of Educational Studies, Universiti Putra Malaysia, \\ Malaysia \\ Correspondence: Jayakaran Mukundan, Department of Language and Humanities Education, Faculty of \\ Educational Studies, Universiti Putra Malaysia, 43400 UPM SERDANG, Selangor, Malaysia. Tel: \\ 60-3-8946-6000. E-mail: jaya@educ.upm.edu.my
}

\author{
Received: July 17, 2013 Accepted: August 10, 2013 Online Published: October 10, 2013 \\ doi:10.5539/elt.v6n11p77 URL: http://dx.doi.org/10.5539/elt.v6n11p77
}

\begin{abstract}
This article presents the results of a study on the experience of the Malaysian secondary school student with Young Adult Literature in the English language classroom. The study aimed to determine the extent to which the Malaysian secondary school student identified with the young adult protagonists and issues in the novelswhich have been prescribed as literary texts in the English language classroom. As the study required in-depth knowledge of young adult students' 'essence of experience' in their engagement with the texts, the method used was phenomenological. The sampling for the study was purposeful and data came from participants' written journal reflections during the reading of the novel and from follow-up qualitative interviews.

In terms of identity and relevance of novels to the young adult participant, the findings revealed a sense of reciprocity, bonding or mediatory role that developed between participant and characters. The identification of participant with familiar issues and characters were significant not only by their presence but also by the absence. Expectations of participants towards adult characters were higher and attitudes tended to be more judgmental and less forgiving compared to young adult protagonists. Participants' responses also indicated the need for literary texts to provide a realistic portrayal of society.

The study has shown how young adults identify with the elements of YAL in literary texts and thus provides valuable information when text selection for young adults needs to be made particularly in the Malaysian context.
\end{abstract}

Keywords: Young Adult Literature (YAL), English as a Second Language (ESL)

\section{Introduction}

The genre of Young Adult Literature (YAL) which also goes by the labels of 'adolescent fiction' or 'teen fiction' almost describes itself by its title as literature that is in some way connected with the young adult. This is in fact true but the evolutionary path of YAL spanning several centuries, has not always been smooth. Its present place as an established genre of literature among other older and more conventional literary genres is partly due to the young adult developmental theories in the past century (Erikson, 1968; Havighurst, 1972; Kohlberg, 1976) The very characteristics of YAL that relate so closely to the issues faced in young adulthood have also made YAL highly relevant to the young adult, thus making it favored as selected reading material for young adult students in many countries (Reed, 1994; Kaywell, 2000; Owen, 2003; Bushman \& Haas, 2006; Yongan, 2008).

In Malaysia however, where the history of literature learning is still relatively new, the popularity of YAL has not yet caught on as selected reading material for students in national secondary schools. Studies on the first set of literary texts used as a compulsory component of the English Language subject in national secondary schools revealed little enthusiasm and interest shown by students due to a lack of relevance and identification with the texts (Lian, 2002; Sidhu, 2003; Subramaniam, 2004). The Curriculum Development Department (CDD) of the Malaysian Ministry of Education (MOE) which is in charge of text selection for the literature component, stated that they have taken the factors of relevance and interest into account and would include 'teenage issues' in their selection of new texts in the $2^{\text {nd }}$ cycle which began in 2010 (Ghani, et al. 2007). The novels thus selected as prescribed reading texts for the Malaysian secondary school student are; Step by Wicked Step (Fine, 1996), Catch us if You Can (McPhail, 2004) and The Curse (Lee, 2010) 
Studies on these texts have not yet been conducted to ascertain the presence of these 'teenage issues' nor the extent of relevance it has to the young adult Malaysian student who will be reading them. An important fact that has to be taken into consideration is that the very experience of reading itself makes the young adults active participants who not only make meaning from the pages but get their personal histories embedded in the creation and interpretation of the text (Fish, 1967; Holland, 1968; Rosenblatt, 1976). Thus, any attempt to discover the extent of relevance and interest shown by Malaysian secondary school students towards these new texts would have to take into account the reality of the young adulthood phase with the issues that come with it and the reality that is constructed during the reading experience.

A study in this direction would require in-depth knowledge of students' engagement with the texts and their personal experiences of the reading. The current literature on Malaysian students responding as young adults to prescribed literary texts in the language classroom is insufficient. Missing also is research in the Malaysian context of the understanding of the experience of the Malaysian young adult student with YAL which is of an in-depth and reflective nature.

\subsection{Objective of the Study}

The present study therefore aimed to address these gaps and provide the information needed on how Malaysian students as young adults themselves, relate to, interpret and identify with the elements of YAL in the prescribed novels of the literature component. This information is crucial as it allows all concerned parties access to information about their reading experience at a deeper level.

\subsection{Research Questions}

In view of the objective mentioned above, the study attempts to answer the following research question:

To what extent do Malaysian students find the novels prescribed as literary texts in the English language classroom relevant to their lives as young adults?

1) To what extent do they identify with the young adult characters in the novels?

2) To what extent do they identify with the issues in the novels?

\section{Literature Review}

\subsection{Defining Young Adults}

Although a definite demarcation of boundaries between adulthood and childhood may be non- existent or subjective and relative to the individual society, a looser definition of young adulthood would refer to the transitory period where a person leaves behind his childhood and embarks on the journey towards adulthood (Nilsen, 2005). This period of young adulthood which is sometimes termed as adolescence, or teenage years, could, at its widest, range between 11 to 22 although a narrower span of about 12 to 19 is generally more accepted (Young Adult Library Services of the American Library Association). However, certain characterizing features of this period that are significant and markedly different from what goes on in childhood and adulthood, provide the period of young adulthood the status of being a distinct phase in human development. This is further confirmed in the works of developmental psychologists such as Erikson, Havighurst and Kohlberg. Psychologist Robert J. Havighurst (1972) in his studies on adolescent psychology defines the 'Lifetime Developmental Tasks' for this same period which include the search for self- identity, achieving of emotional independence from parents and other adults, acquiring a personal ideology, adapting to physical changes and forming a perception of self in relation to the opposite sex.

\subsection{Defining the Literary Genre of Young Adult Literature}

Compared to other literary genres, the consideration of YAL as being a literary genre on its own is relatively recent and not without skepticism. In the past, YAL has often been viewed in the same way adolescence itself is viewed, which is, as a period of uncertainty and without clear definition (Cart, 2001; Cole, 2008). Significant milestones that have contributed to the shifting of attitudes in the history of YAL include the publication of novels such as The Catcher in the Rye (Salinger J. D., 1951) and The Outsiders (Hinton, S. E., 1967) and later on Paul Zindel'sThe Pigman (1968) and My Darling My Hamburger (1969). Featuring teenage protagonists, these novels have been credited as being pivotal in the shift to new realism and were also acclaimed by critics for their frankness, honesty, high quality of writing and ability to relate emotionally with their readers.

With the subsequent emergence of an adolescent market, young adult sections were thus created and given many names including 'Literature for Adolescence', 'Adolescent Fiction' and 'Teen Novels.' While the young adult novels of the 1970's and 1980's were referred to as 'problem novels' in that they depicted the issues faced by adolescents, in the 1990's the topics explored in young adult novels became more diversified and included 
previously controversial topics and marginalized characters such as gay or transgender characters as protagonists (Elliot \& Dupuis, 2002). In the 1990's the evolution of YAL became more evident with multiple narrators, multilayers, non-linear time sequences and the incorporation of visual elements (Capan, 1992; Campbell 2004; Prokou 2005). Within the genre of YAL there began to be overlapping of themes (Smith 2007; Stephens, 2007). The establishing of the Michael L. Printz Award for Excellence in Young Adult Literature in 1999 also signified another milestone for YAL and served to vindicate it to some measure from the criticisms of being 'less than literary' or nothing more than 'a superficial reading experience' leveled at it by some groups.

Although YAL has remained a controversial issue even to the present moment with a number of academics still viewing it in a negative light (Cart, 2001), throughout the years YAL writing has produced work of increasingly higher literary merit.

\subsection{Issues in $Y A L$}

The broad and widely accepted definition of Young Adult Literature (YAL) would be literature that is written for, published and marketed to young adults (Young Adult Library Services of the American Library Association, 2011). It could also be as defined by Nilsen and Donelson (2005), 'anything that readers between the approximate ages of 12 to 18 would choose to read'. Both definitions are not necessarily mutually exclusive as reading choices made by young adults may be related to what is relevant to their own lives and the issues they are facing. It is very likely that young adults would independently choose to read books that are meaningful reflections of their own thoughts about growing up. They may also seek vicarious experiences in the text by identifying with the young adult protagonists in the story. In short they would want to read stories about themselves (Reed, 1994; Chance, 1999; Wolf, 2007). These same preferences are in fact elements of YAL and belong to the list of identifying criteria for YAL as stated by Brozo and Simpson (1995) and Small (1992). These criteria include the depiction of a young adult protagonist at the center of the plot who is perceptive, sensitive, intelligent, mature and independent; themes that are contemporary and meaningful to young adults and events or problems pertinent to the lives of the young adult or related to them. It is the 'voice' of the young adult that is projected. The actions and decisions of the main young adult characters are major factors in the outcome of the conflict. The fictitious depiction of adolescent experiences may have a strong impact on teenage readers at this stage of their lives, and by identifying with the characters in the novels who they can relate to, young people may actually acquire a sympathetic companion in times of uncertainty and confusion (Herz \& Gallo, 1996, Kaplan, 2007).

\subsection{Literary Theory in YAL and Reading Development}

If YAL is more truly defined by what young adults would choose to read independently (Niles and Donelson, 2005), then it follows that the texts of YAL may either determine their own reading or be determined by the reading (Moore, 1997). The reader's interpretive ability and the state of mind it induces in them would also play a significant role in distinguishing YAL from other literary genres. This in fact corresponds to Reader-response theory which sees the reader as an active participant who produces a unique reading experience because he brings into the reading experience his own physical and psychological conditions causing his personal history to become entrenched into the creation and interpretation of the text (Fish, 1967; Holland, 1968; Rosenblatt, 1976).

In line with most contemporary interpretations of the Reader-response theory and lifetime developmental tasks, YAL bears the adolescent reader in mind, and it is the characteristic of being both written for the reader and the reader choosing to read this above other forms of literature that have the potential to place YAL in a more favorable position compared to other literary genres when choices of suitable reading material for adolescents have to be made (Cart, 2008)

\subsection{Literature in the Malaysian English Language Classroom}

\subsubsection{Introduction of the Literature Component}

The move to incorporate Literature in English as a component of the English language subject in Malaysian secondary schools in 2000 signified the formal acknowledgement of the role of literature in English Language teaching in Malaysia (Curriculum Development Department, Ministry of Education, Malaysia) The prescribed texts for this component combined poems, short stories and novels, and one out of five English teaching periods a week was allotted to teaching the literature component. Among the objectives of this move were the desire to increase students' proficiency in English, as well as to contribute towards personal development and character building (MOE document 1999). After the end of the first cycle (2000-2010), in which the novels used were found to be 'uninteresting incompatible, and depressing, and without 'appeal to the targeted students' (Vethamani, 2003; Too, 2004; Ghani et al, 2007), the second cycle of literary texts were projected to include texts with young adult issues that students could identify with and respond to emotionally. 
Following is a brief description of the three novels.

\subsubsection{Step by Wicked Step by Anne Fine}

Five children on a school trip arrive earlier than their other school mates at Old Harwick hall on a stormy night where they discover an old journal by a boy Richard Clayton Harwick who lived there once. Richard's Story 'Read and Weep' recounts his unhappy life after his father dies and his mother remarries Reverend Coldstone. The children read about the trail of heartbreak that follows Richard's decision to run away from home. This in turn prompts the five children Claudia, Colin, Ralph, Pixie and Robbo to share their own stories of the situations in their families which involve their parents break-ups, remarriages, new partners, coping with the new step-parents and step-siblings and of coming to terms with all these. It is also at this point that they discover the common bond they share with each other which is also reason they have been selected to travel together.

\subsubsection{Catch Us if You Can by Catherine McPhail}

Rory and his grandfather whom he calls 'Granda' live in a flat and they share a unique relationship. The two only have each other since Rory's father left them when he was a baby. Rory, apart from looking after his old Granda's increasing health needs and medication, also has to deal with schoolwork at the same time. Although Rory is completely attached and devoted to his Granda, his grandfather's increasing forgetfulness and need for care makes it very difficult for him to juggle between looking after his grandfather and attending to his schoolwork at the same time. After Grandaaccidentally sets a fire in the kitchen, he is placed in Rachnadar, an old folk's home, while Rory has to go to a children's home in Castle Street. Both Rory and his grandfather are devastated by the separation and being unable to stand by and watch his grandfather slowly losing his spirit to live, Rory makes a bold decision to 'escape'.'Catch Us If You Can' tells the story of their escape journey, their adventures and the amazing people they meet on the way whose lives become significantly interwoven with their own.

\subsubsection{The Curse by Lee Su Ann}

Azreen, who is a student in London returns to her island village when she gets news of her sister Madhuri's sudden death. Azreen is unconvinced that her sister's death was due to natural causes and sets out to find the truth. Apart from following her instincts and suspicions about the mysterious circumstances surrounding her sister's death, she has to deal with her own unresolved and conflicting feelings of jealousy towards her dead sister, the reluctance of her father to discuss the matter, her mother's increasing senility and the superstitious connections made by the villagers between Madhuri's death and the legendary 'Mahsuri' curse on the island

\section{Methodology}

\subsection{Research Design: Why Qualitative Research?}

As the aim of the present study was to understand and learn from the phenomenon of adolescent ESL students in the Malaysian classroom responding to YAL in their prescribed literary texts, the method that best suited the purpose of the study had to be qualitative in nature (Merriam, 2009; Richards, 2010). In-depth reflective descriptions of the participants' experience of adolescence in relation to the literary text, were needed and so the approach was naturalistic and the research interpretive (Guba\& Lincoln, 1985; Creswell, 2003).

The experiences of the young adult Malaysian student responding to elements of YAL in the literary texts were personal and subjective and their interpretations were fused with their own experience of young adulthood. This therefore became a personal form of reality which was unique to the young adult himself. Phenomenology provided the researcher the medium by which the essence of an experience, like the one in the present study, could be derived through a descriptive, reflective, interpretive and engaging mode of inquiry (Van Manen, 1990; Reid, Flowers \& Larkin 2005). It also allowed the researcher to do justice to the complexity of interpretations of meanings of the participants' experiences.

In the present study qualitative interviews and reflective journals were used to gather the data that was needed.

\subsection{Procedures}

\subsubsection{Selection of Participants}

The sampling for the study was purposeful and eight students with suitable English proficiency and who professed to be independent readers were selected from the fourth form in a Malaysian national type secondary with the help of the school's 'Student Information System' teacher and the support and agreement of the school. After the participants were briefed about the study and consent obtained, they were supplied with the three novels and a set of guidelines on what was expected from them in the writing of their journals. 


\subsubsection{Qualitative Interviews}

Qualitative interviews were used as a method in this study as the researcher needed to gather deep information concerning the participant young adults' thoughts, feelings and perceptions related to the YAL elements in the texts (Guest, Bunce\& Johnson, 2011). A semi-structured interview protocol including open-ended questions was constructed to cover the required scope of the research questions. Qualitative interviews were then conducted with each participant. Although certain guiding questions were used during the interviews they were not fully structured to allow the participants free expression of feelings, thoughts, responses and perceptions without the hindrance and constraints of pre-set question requirements. Also, as the objective of the study was closely related to young adults' perceptions of themselves and their experiences and conflicts of this period, qualitative interviewing allowed the co-construction of the data and knowledge through the dialogue between researcher and participants (Kvale, 1996; Mason, 2002). In fact, it was the responses of the participants that determined the direction of the interviews and provided a better guide to the form of questioning, not the other way round.

All interviews were recorded and transcriptions were made soon after each interview by the researcher listening to the recording and transcribing directly onto the computer. Duringthe transcribing process further related reflections of the researcher were added.The researcher also took the transcriptions of the interviews back to the participants for them to read before they were subject to further analysis.

\subsubsection{Reflective Journals}

Reflective journals represent a form of self-observation, introspection and retrospection. Studies of reflective journals involve systematic personal accounts of feelings, thoughts, beliefs, attitudes and reactions over a period of time. Reflective journals are also important introspective tools which are particularly suited for descriptive and interpretive research and for 'investigating behaviour in context' (Nunan, 1992; Morse \& Richards, 2007).

Apart from qualitative interviews, the present study also used data gathered from the participants' written reflections in their journals during their reading of the three novels. These reflections were loosely based on a set of guiding criteria provided by the researcher in line with the research questions. While the qualitative interview procedure sought to elicit responses of the same nature regarding the participants' experiences with the novels, the study took into consideration the possibility that the participants may rather write down than speak about particular thoughts, feelings or experiences in the context of the study especially if they were of an extremely personal nature. The data gathered from the participants' written reflections during their reading of the three novels dealt with young adults' personal responses, their feelings and thoughts in relation to the novels that are being read.Results of a pilot study conducted on one of the eight participants indicated that guidelines on the journal reflections needed to be emphasized and elaborated again to the participants.

\subsubsection{Data Analysis}

Data analysis in this study was an on-going process. Apart from the reflective journals and qualitative interviews, data for the study also came from the field notes of the researcher. Further reflections and notes of the researcher were added during the reading of the reflective journals, the listening to and transcription of the interviews. The data of all parts of the study were read a few times to obtain a preliminary analysis of general themes and ideas. The emergence of specific units or segments of information were recorded and reduced to themes relevant to the research questions. The data was also examined for clustering of units. Analytic coding was used to develop themes as categories and subtopics emerged.

A thick description was then written based on the themes that emerged during the analysis. A comparison was then done between all parts of the study to confirm the findings and to answer the research questions. Feedback from member checks guided the researcher to examine the data further in case of discrepancies between findings and data and to confirm and triangulate earlier findings.

\section{Results and Discussion}

The main research question of the study was:

To what extent do Malaysian students find the novels prescribed as literary texts in the English language classroom relevant to their lives as young adults?

1) To what extent do they identify with the young adult characters in the novels?

2) To what extent do they identify with the issues in the novels?

\subsection{Identification with Young Adult Characters}

Although initial responses showed little identification of the participants with the young adult protagonists in the 
novels, as the study progressed there appeared more evidence of them seeing themselves both directly and indirectly. While none of the participants identified completely with any young adult protagonist in the novels, most of them saw glimpses of themselves in the novels although in varying degrees and in different characters.

Generally the characters that the participants could identify with tended to be of their own sex but there were exceptions. Although none of the boy participants mentioned that they were like any female young adult protagonists in any way, the same was not true for girl participants whose references to characters they could identify with were not confined to female protagonists only.

\subsubsection{Believability and a Sense of Kinship in Catch Us If You Can}

In comparing themselves with Rory, the young adult protagonist in Catch Us If You Can, four participants felt that they couldn't measure up to Rory's strength of character and one of them stated that she 'couldn't do what Rory did.' What stood out most in the character of Rory was his maturity beyond his years which seemed to almost intimidate some of the participants who felt they couldn't measure up. However, unlike the young adult protagonist Azreen from The Curse, the participants found no artificiality attached to the depiction of Rory. They saw him as someone who had been hurriedly forced to grow up, they both admired and sympathized with him for this and held themselves up against this maturity almost wishfully. The participants conceded that even though the situation of having to assume adult responsibilities at such a young age was unique and not a common situation for a young adult, there were no hints of berating or any criticism leveled at Rory himself. Any lack of believability they felt, lay in the whole situation itself of 'escaping from their homes and running half way across the country'. Also, this novel elicited a sense of defensiveness towards the character of Rory almost as if they were defending a younger and more vulnerable member of their own group. On the whole there was a sense of protectiveness towards the character of Rory, not unlike one they may feel towards a real person who was the runt or weakest in their clique. This feeling of kinship or inclusion by the young adult participants towards 'one of their own' does suggest a form of loyalty that is extended to a universal population of young adults whether fictional or real. Thus when this loyalty and defensiveness is projected even towards fictional young adults it shows that they have identified with them not just as an individual but as a representation of their own young adulthood. At other times they also assume the role of being mediator between generations and become the ones who see both sides of the situation and dish out advice to both warring parties.

On the other hand, one of the participants, Pam when comparing herself with Rory, expressed feelings of inadequacy and is almost self- deprecatory when she says 'I'm useless'. In her journal entries related to this novel, she withdraws into a form of angst filled self- condemnation when she refers to herself as 'ugly and a criminal in the dark.' This could be something else to consider in the selection of Young Adult novels, whether the presentation of characters who are too strong could cause a kind of intimidation in the young adult readers.

\subsubsection{Rejection of the Young Adult Protagonist in The Curse}

There was also a form of relationship drawn in instances where the participants felt an inconsistency between their own projected reactions and that of the young adult protagonists. This was the case with Kay, who unlike the other girl participants did not make comparisons between her own headstrong and outspoken nature with that of Azreen (The Curse). In fact, her complete rejection of the character of Azreen as being contrived, artificial and being too much of a 'martyr' to be considered real, can be viewed even as a form of counter identification. She is familiar with the cultural setting and has an idea of what a teenager from that setting and background should be like, and seeing a version that doesn't coincide with what she knows to be real arouses a kind of annoyance which she expresses vehemently in her writing and speech. What is interesting here is that among all the participants she is closest to the setting culturally and yet alienates herself deliberately from the depiction of its protagonist. This actually raises the question of how important authenticity in the depiction of characters is to an audience that is not familiar with the setting. In a situation where a literature text needs to be selected for young adult students, would it be preferable to choose themes that are of relevance to the young adult but belonging to cultural settings and backgrounds that are not too close to the readers to prevent an over- critical scrutiny by the more discerning students?

\subsubsection{Projection of Self into Step by Wicked Step}

A reverse form of vicarious identification also seems to be at play in some cases. When another participant Beth, talks about the young adult protagonist Claudia from Step by Wicked Step, it is she who proffers advice to the fictional character. Rather than applying Claudia's predicament to her own, Beth has decided that it is Claudia who should take a page from her. In a sense she appears to have walked through a 'looking glass' to the other side, to Claudia's world and is now comforting Claudia with what she herself has gone through. The fact that Beth does it so naturally brings to light the possibility that identifying with the text is not just about the young 
adult 'receiving' from a character but it also involves what they voluntarily 'offer' to the character. It is about being someone who has experienced all that the character is now experiencing and is therefore now in a position to point the way for the fictional young adult character in the novel. So not only have they identified with the character, they have actually gone into the novel and at times have bid the character to come over to their side. For an instant there seemed to the researcher a kind of confusion between the participant and the fictional character; which one was real. It also provided an insight into how the young adult participants saw themselves in their reading. Besides projecting themselves into the novels, they have allowed the young adult characters to step out from the novels and be part of their own world. So the phenomenon of this reading experience is unique in that it is like a two way mirror that allows characters from both sides of reality to pass through the dividing lines, namely, the pages of the book in the young adult novel.

In line with the developmental theories of young adulthood (Havighurst,1972; Erikson,1968) this is the period when young adults' perceptions of their self-identity and place in society begin to form and as they prepare to leave childhood for adulthood the division between reality and fantasy becomes more well-defined in their minds Though at times they slip back into the fantasy world of childhood they don't remain there for long. The 'alternate reality' which they may experience through vicarious identification with YAL may in fact be used to great advantage by counselors and therapists in the country for bibliotherapy especially by those working with troubled youth.

\subsection{Identification with Issues}

Although the direct identification with characters or seeing themselves as any particular character in the novels was not obvious, there was a definite relating to a significant number of issues that were highlighted in the novels. The participants found that they could relate to a number of issues in the novels, chief of which were the subjects of broken homes, failed relationships, divorce, remarriage, family bonds, acceptance and coming to terms with reality.

\subsubsection{Dealing with Broken Homes}

Participants who had experienced the break-up of their parents' marriages gave responses that were poignant and revealing of their own feelings of helplessness, confusion and resignation when faced with similar situations in their own homes. Beth, in her journal, writes about the feeling of coming back to an empty house and says she understands how Claudia (Step by Wicked Step) feels 'when furniture and household items are in disorder'. This is strongly suggestive of her own personal experience of a similar situation. As trivial as a disordered room portrayed in a novel may seem, its significance is felt by Beth because she has gone through it and knows what it feels like. Her experience of coping with a new step-parent or 'substitute' parent is recorded with some anguish in her journal after she writes about the teenage protagonist Claudia's experience. Other participants who were more tight-lipped at the beginning (Eddie, Sam) began to open up voluntarily during the discussion of this novel and proceeded to describe rather emotionally their feelings when there were fights between their parents and how it felt like when one parent chose to have an extra-marital affair. Even in cases where participants came from happy and stable homes it seemed to make them stop and ponder about what really went on in the homes and lives of their friends who were going through similar situations and what words like 'pre-divorce sessions' and 'marriage counseling' meant. In a way it made them face the realities of these situations in their contemporary society.

The question that arises from this however is how relevant issues of family split-ups and marital problems were to young adults who don't go through this and whether it was fair to load this on them almost forcibly. Another emerging thought about this is how far relevance and reality needed to converge in deciding the extent of what was considered Young Adult elements in novels that are prescribed for our students. If there were young adults who passed this transition phase smoothly without any major upheavals, how relevant to them would be Young Adult novels which centered around growing up problems?

\subsubsection{Relationship with Step-Parents}

Another situation that seemed to relate closely with some of the participants (Sam, Eddie) was the relationship between the young adult protagonist Colin and his step-father (The Bluebird of Happiness: Step by Wicked Step). In comparison to the other participants, it is Sam who responds most to this especially when he goes on to talk about his own relationship with his father whom he had described as having no time at all for him apart from a 'Hi and a Bye.' The sense of wistful yearning that comes across when he talks about this again reminds and reinforces the idea of the significant effect issues that are of relevance have on the emotions of young people and its subsequent power to evoke other emotions such as envy against the characters who have what they themselves don't possess. To the researcher this situation evokes an image of the young adult stepping into the 
novel, confronting the character,shaking him by the collar and demanding answers for questions such as 'Why is it that you have what I don't?' or 'Why are you better off than me?' This is also equally convincing of the emerging phenomenon in the study that identification of issues and characters is not only by presence of familiar issues but also by the absence.

\subsubsection{Shifting of Perspectives}

While the depiction of the situation in the family evokes the reader's sympathy towards Colin and his step-father and casts a bad light on his mother for being the one who has caused the separation and thereby the anguish, two of the participants actually managed to view the situation through the eyes of the mother and wondered if her reasons for leaving were not somewhat justified. This capacity for being able to take the other person's side in the light of popular opinion is again indicative of the participants' own stage of development where they can switch from childish longings for warmth and security to being able to look at things objectively and from a very 'adult' perspective. The important thing about this as it relates to the features of YAL which is usually written from the first person (young adult protagonist)'s point of view, is that the young adult reader is able to move from this position to viewing the bigger picture. He does not necessarily agree with the way things are presented by the young adult protagonist and in fact like in the case of Colin's stepdad, looks for reasons which are not even expressed by the writer. What this does say about YAL is that it is possibly not only young adults who find it relevant, but like literary work of other genres it has the power to draw the reader and shift his perspective to that of the young adult. On the other hand it can also transform the young adult reader momentarily to be a kind of 'judgmental adult'

\subsubsection{Dealing with Expectations}

There is also a lot of emotions in participants' responses towards the parts of the novels that make them think about some of the less pleasant issues they face in their own young adulthood and how difficult it is for them sometimes to get adults to listen to them and treat them as if they really exist. The problem of acknowledging and recognizing young adulthood as a separate phase of life, which has been present throughout the centuries is thus highlighted in the study through the reflections of the participants who feel they are sometimes treated as 'invisible' with adults having either 'over-expectations' or 'under-expectations' of them. This comes across in their writings and the sometimes brooding ways they refer to this. Interestingly it is usually directly after they have dished out optimism and advice to a depressed character in the novels that they themselves retreat and become introspective.

\subsubsection{Sibling Rivalry}

Other issues that they identified with were sibling rivalry portrayed in the novels. In its milder form they spoke about everyday squabbles and fight over insignificant things like the remote control or preferred seating places in the living room. The much darker and more deep-seated resentment of Azreen in The Curse towards her dead sister Madhuri became a catalyst for one participant's venting of her frustration against her parents' perceived preference of her younger brother over her which has at times made her feel unwanted, unloved and even prompted the idea of leaving home.

\subsubsection{Relationship with Grandparents}

The relationship between participants and their grandparents was also a subject that was dwelt upon by many of the participants after they had read Catch Us If You Can.Reading about the special bond between Rory and his 'Granda' evoked fond recollections of their own grandparents and the role they had played in their lives. This was highlighted even by those who did not have such a bond with their grandparents and translated into a kind of wishful thinking and fond hopefulness which in turn seems to suggest a lapse into childhood fantasies of the old, absent-minded but lovable, archetypical grandparent. It is uncertain if this has to do with their own Asian family values and whether the same kind of responses would be present among teenagers in another setting. Nevertheless the sympathy and understanding they felt for grandparents which was not obvious in discussions over parents in the novels was a serendipitous finding in the study.

\section{Conclusion}

The study dealt with Young Adult Literature in the Malaysian classroom and its objective was to explore the responses of the Malaysian young adult student towards these novels. The findings from the study were projected to be significant in determining the extent to which these texts fulfilled the objectives of relevance to the young adult student as set by the curriculum planners. The findings would also describe the extent to which the young adult student has identified with the texts on a personal level and how he relates to them.

Identification with young adult characters and issues in the novels was present in varying degrees and differed 
from one participant to another. Comparisons that were made between participant and character depended on their own backgrounds, family situations and issues that they themselves were facing, chief of which were issues of broken homes, failed relationships, divorce, remarriage, family bonds, acceptance and coming to terms with reality. Several participants who came from homes where their parents were separated, divorced or estranged identified strongly with the emotions and actions of the young adult characters in Step by Wicked Step.

There was also a form of 'counter-identification' with young adult protagonists in the novels when the participants felt that they could not measure up to the strength of the character. This was true in the case of Rory in Catch Us If You Can who had displayed strength of character that was beyond what was expected at his age. Although Rory was perceived as someone who had been hurriedly forced to grow up, the participants both admired and sympathized with him for this and held themselves up against this maturity almost wishfully. On the other hand, the character of Azreen in The Curse was perceived as being contrived and artificial, giving rise to the question about whether a setting that is too close to home may cause young adult readers to be more critical or judgmental than if it happened in a setting that was less familiar culturally.

There was also a sense of empathy and common bonding or 'kinship' that developed between participant and characters which elicited responses indicating indignation, protectiveness, loyalty and defensiveness towards the character when the occasion rose which further illustrated their identification with the characters. This again was more evident in Step by Wicked Step and Catch Us If You Can compared to The Curse. There were also instances when the young adult participants assumed the role of a mediator between the generations in the novels or served as counselors who proffer advice to the young adult protagonists thus illustrating a kind of crossing over into the fictional world of the novel. This in turn, points towards the existence of a two-way path between young adult reader and novel where the young adult reciprocates by giving to the novel instead of just receiving from it.

The responses of young adult participants who came from backgrounds that were unlike those depicted in the novels indicated that they understood, even if they couldn't feel the emotions of the situations. This however brought to surface the question of whether there really existed a universal relevance of YAL for the young adult and the extent to which relevance and reality needed to converge in YAL before it could be considered suitable in prescribed texts for the classroom.

Another thought that emerges from the study is that identification of issues and characters that are familiar is significant not only by their presence but also by the absence as in the case of the special bond between Rory and his grandfather in Catch Us If You Can whichleft some of the participants fondly wishful. The young adult reader is also at certain points, able to move from his own position as young adult and adopt a more objective perspective of situations which is indicative of a maturity that is more commonly associated with adulthood.

On the whole, the young adult readers were more understanding, forgiving and non-judgmental of the actions or decisions made by young adult protagonists in the novels, becoming even advocates at times for their rights, even if they were not always the right ones. This kinder and more accommodating attitude was also projected towards the grandparents' generation. However, when it came to other adult characters, they were less forgiving and at times rather harshly critical. Their responses towards the adults in the novels generally indicated that they had much higher expectations and standards of behaviour of them and were less tolerant of their human weaknesses.

The findings of the study apart from providing answers to how the young adults identified with these elements also provided glimpses of the many issues that young adults had to contend with at this phase of their lives.

\section{Recommendations}

These findings have significant implications to the Malaysian panel who decides text selection for the young adult Malaysian student in secondary schools because it illustrates the impact YAL can have on their thoughts and emotions, not only outwardly towards the novels but inwardly as they begin introspective reflection and make comparisons with their own lives. A point that curriculum planners may need to note is how young adults are affected by decisions taken by young adult characters in the novels, such as running away from home and may need to remember the possible outcomes on more vulnerable teens. This does not however mean that they need to choose only texts that present a wholesome depiction of model 'submissive and obedient' young adults as this would reduce the believability of the novels. Young adults who are able to discern between what is real and contrived may in fact be put off by the too-perfect depiction of young adult characters in the novel. Young adult characters who like them, go through periods of uncertainty, who are both strong and weak at the same time, who have simultaneous moments of childhood and adulthood, who make mistakes, who may take a beating now and then, who may become crushed by their own actions and yet not completely, who take wrong turns sometimes but are able to get back - are the ones they are most likely to relate to and this identification of a 
kindred spirit will make them form attachment and want to continue reading.

In the matter of deliberately looking for local content, this should not overshadow the need for the novel to relate to the young adult regardless of cultural context. This was brought home very clearly in the study where the young adults related most to issues that were familiar rather than contexts and settings that were familiar.

Although the study used the three prescribed novels to determine the responses of the Malaysian young adult student towards YAL, the findings reflected the reading journey of the young adults, how they drew parallels between what was going on in the novels and their own emotions, fears, feelings, angst, successes and at times frustrations. This was possible due to the qualitative nature of the study itself and the phenomenological approach which sought to uncover the essence of the young adult's experience with text. An approach that was less introspective may not have been as effective in eliciting the emergent deep responses that are so crucial in the study of an experience of young adulthood and text. Thus future research could be done using participants of specified language proficiencies to see what differences may result. A similar study using other novels may also be done to determine if there were differences in the way young adults of different sexes respond to the same novels. Research could also be carried out on responses towards specific elements of YAL such as teenage expressions and descriptions.

The cycle of novels in the Malaysian school will eventually change according to administrative policies but the issues faced by young adults in this period of development would for the major part remain the same. Another question that surfaces is how different would the findings of the study have been if the novels used had no elements of YAL in them. Would the reading experience be the same and would young adults still endeavor to seek representations of themselves in what they read? Would they attemptto 'squeeze' out whatever relevance they could find or be content if they find the novels interesting and enjoyable enough despite lack of relevance? Thus comparative studies can also be done using novels that belong to the YAL genre and those that do not. This and the questions raised earlier may become subjects of future research.

\section{References}

Brozo, G. W., \& Simpson, M. L. (2006). Content literacy for today's adolescents: Honoring diversity and building competence. New Jersey: Pearson.

Bushman, J. H., \& Haas, P. K. (2004). Using young adult literature in the English classroom. New York: Random House.

Bushman, J. H., \& Haas, K. P. (2006). Young adult literature in the English classroom (4th ed.). New Jersey: Pearson.

Campbell, P. (2004). YA biblio-bullish trends. Horn Book Magazine, 80, 61-66.

Capan, M. A. (1992, November). Multiple voices in young adult novels. Paper presented at the 84th Annual Meeting of the National Council of Teachers of English. Louisville, Kentucky.

Cart, M. (2001). From insider to outsider: The evolution of young adult literature. Voices from the middle, 9(2), 95-97.

Cart, M. (2008). The value of young adult literature. Lanham, MD: Scarecrow Press.

Chiu, C. H. (2007). New immigrant readers: The role of young adult literature in literacy development and academic confidence. Unpublished doctoral dissertation. North Carolina State University, Raleigh.

Creswell, W. J. (2003). Research design: Qualitative, quantitative, and mixed method approaches (2nd ed.). Thousand Oaks, CA: Sage Publications.

Cole, P. (2008). Young adult literature in the 21st Century. New York: McGraw-Hill.

Donelson, K. L., \& Nilsen, A. P. (2005). Literature for today's young adults (7th ed.). Boston: Pearson.

Elliot, B. J., \& Dupuis, M. M. (2002). Young adult literature in the classroom. Newark: International Reading Association Inc.

Erikson, E. H. (1968). Identity, youth and crisis. New York: Norton.

Fine, A. (1996). Step by Wicked Step. London: Puffin Books.

Fish, S. E. (1980). Is there a text in this class? The authority of interpretive communities. Cambridge, MA: Harvard University Press, 1980.

Ghani, A. H., Bakar, A. M., Salim, S., \& Shukor, M. (2007). Implementation of the English language literature component for secondary schools: An impact study. Journal of Educational Research. Educational Research 
and Planning UnitMinistry of Education Malaysia.

Guba, G., \& Lincoln, Y. S. (1985). Naturalistic Inquiry. California: Sage Publications, Inc.

Guest, G., Bunce, A., \& Johnson, L. (2011). How many interviews are enough? An experiment with data saturation and variability. Field Methods, 18, 59-82.

Herz, S. K., \& Gallo, D. R. (1996). From Hinton to Hamlet. Westport: Greenwood Press.

Hinton, S. E. (1967). The Outsiders. New York: Viking.

Holland, N. (1968). The dynamics of literary response. Oxford: Oxford University Press.

Kaplan, J. S. (2005). Recent research in young adult literature: Moving beyond traditional constraints and convention. The ALAN Review, 11-18.

Kaywell, J. F. (2000). Adolescent literature as a complement to the classics. Norwood: Christopher-Gordon Publishers Inc.

Lee, Su Ann. (2010). The Curse. Kuala Lumpur: Utusan Publications and Distributors Sdn. Bhd with the Ministry of Education Malaysia.

Macphail, C. (2004). Catch Us If You Can. London: Puffin Books.

Morse, M. J., \& Richards, L. (2007). Read me first for a user's guide to qualitative methods (2nd ed.). Thousand Oaks, California: Sage Publications.

Merriam, B. S. (2009). Qualitative research: A guide to design and implementation. San Francisco: Jossey-Bass.

Ministry of Education, Malaysia. (2009). Literature component for secondary schools: A collection of short stories and drama Form 4 and 5. Kuala Lumpur: Perpustakaan Negara Malaysia.

Ministry of Education, Malaysia. (2009). Literature component for secondary schools: A collection of poems, short stories and drama Form 1 to Form 3. Kuala Lumpur: Perpustakaan Negara Malaysia.

Moore, J. N. (1997). Interpreting young adult literature: Literature theory in secondary classroom. Portsmouth, NH: Heinemann.

Nilsen, A. P., \& Donelson, K. L. (2001). Literature for today's young adults (6th ed.). New York: Addison-Wesley.

Owen, M. (2003). Developing a love of reading: Why young adult literature is important. Retrieved from http://www.alia.org.aU/publishing/orana/39.1/owen.html

Proukou, K. (2005). Young adult literature: Rite of passage or rite of its own. The ALAN Review.

Richards, L. (2010). Handling Qualitative Data a Practical Guide. London: SAGE Publications Ltd.

Rosenblatt, L. (1976). Literature as exploration. New York: Modern Language Association of America.

Reid, K., Flowers, P., \& Larkin, M. (2005). Exploring lived experience: An introduction to interpretative phenomenological analysis. The Psychologist, 18(1), 20-23.

Salinger, J. D. (1951). The Catcher in the Rye. Hardmondsworth: Penguin Books Ltd.

Sidhu, G. K. (2003). Literature in the language classroom: Seeing through the eyes of learners. In G. Subramaniam (Ed.), Teaching Literature in ESL/EFL Contexts (pp. 88-110). Petaling Jaya, Malaysia: Sasbadi Sdn. Bhd.

Smith, S. (2007). The Death of Genre. The ALAN Review. Retrieved from http://scholar.lib.vt.edu/ejournals/ALAN/v35n1/smith.html

Stephens, J. (2007). Young adult: A book by any other name. The ALAN Review. Retrieved form http://scholar.lib.vt.edu/ejournals/ALAN/v35n1/stephens.html

Subramaniam, G., \& Vethamani, M. E. (2004). Teaching of literature in ESL/EFL contexts. Petaling Jaya, Kuala Lumpur: Sasbadi Sdn. Bhd.

Too, Wei-Keong. (2004). Young adult literature: An alternative genre in the classroom reading list. The English Teacher, 35, 41-59.

Van Manen, M. (1994). Pedagogy, virtue and narrative identity in teaching. Curriculum Inquiry, OISE, 4(2), 135-170.

Vethamani, Malachi Edwin. (2003). Developments in teaching of literature in English. Serdang: Universiti Putra Press.

Wolf, L. J. (2007). Young adult novels and the teens who read them. Stanford: Stanford University Press. 
Yongan, Wu. (2008). Teaching YAL to ESL students: An experiment. Oklahoma: University of Oklahoma. Zindel, P. (1968). The Pigman. New York: Harper-Trophy.

Zindel, P. (1969). My Darling My Hamburger. New York: Harper-Trophy.

\section{Copyrights}

Copyright for this article is retained by the author(s), with first publication rights granted to the journal.

This is an open-access article distributed under the terms and conditions of the Creative Commons Attribution license (http://creativecommons.org/licenses/by/3.0/). 